\title{
Community restructuring and sociocultural interaction identity of orang laut (kuala) in the state of Johor
}

\author{
Maryam Syafiqha Mohd. Sayuti ${ }^{1}$, Awang Azman Awang Pawi ${ }^{2}$ Jamilah Omar $^{3}$
}

Department of Socio-Cultural, Academy of Malay Studies, Universiti Malaya, Kuala Lumpur, Malaysia ${ }^{1,2}$ Faculty of Art, Computing and Creative Industry, Universiti Pendidikan Sultan Idris, Tanjong Malim, Perak, Malaysia $^{3}$

\begin{abstract}
This study will look at how this process occurs among the Orang Laut (Kuala) in Johor. This study was carried out to analyse the restructuring of the community and the identification of indigeneous ethnic (Orang Laut) socialcultural interactions in Rengit, Minyak Beku and Kota Masai Johor. In particular, the study will involve aspects of the sociocultural life of the Orang Kuala Rengit, Minyak Beku and Kota Masai Johor, which include languages, economic activities, customs, and practices that are still practiced and things that have been modified in accordance with the factors around them. Analysing the process of adaptation is done closely by relating the process of interactions within groups, local communities, government agencies and the adaptation patterns that occurred. Besides that, the sustainability and the preservation of ethnic cultures of Orang Kuala in the social system as a whole and their impact on the development of the structure of community are examined. Qualitative method is used assisted by other study materials obtained such as field work, observation, ethnographic which are reinforced with library research such as documents and other materials related. This paper will cover the restructuring process by explaining the concepts, books and previous research reviewed by the researcher.
\end{abstract}

Key words: Orang Kuala, restructuring, sociocultural identity

\section{Introduction}

The problem of community restructuring has begun the past. Among the Indigenous peoples of Malaya, restructuring problems are often linked to life activities, social systems and cultural activities from generation to generation. One of the factors leading to community restructuring is to eradicate the poverty that occurs in a society, (Just Faaland, Jack Parkinson \& Rais Saniman, 2002). This scenario also involves the Orang Asli community that is part of the indigenous community in Malaya and subsequently due to the expansion and transformation of the political administration system into Malaysia.

According to Giddens (2011), the backwardness and retardation of a society's life stems from the internal aspects of the society. Therefore, the real cause of the external factors of the community is not to dictate the traditional lifestyle system that prevents them from achieving sustainable living. Hence, this decline is due to the development of international economic networks following the occurrence of colonization in a society.

The concept of identity has been studied, analyzed and discussed by some scholars. Identity is a characteristic or unique or characteristic and personality for each individual as well as for a group (Giddens, 2008). In addition, identity is a set of meanings and experiences that contain an explanation of who an individual is or a group based on selfesteem and in the outsourcing of others (Giddens, 2008, Castell, 2004). Indigenous people in this study refer to the

*Corresponding author: maryamsayuti@gmail.com 
Orang Kuala who have been said to have once made the sea their home in the shores of the Straits of Malacca Strait and Riau Islands. They are associated with the development of the Malay Sultanate of Malacca and Johor and has begun to change the culture of life, beliefs, and economics and become part of other groups of people who then affect the overall structure of the Orang Kuala community. Also states in many parts of the Sulalatus Salatin, the role of Orang Laut in the Straits of Malacca pictures acts as the straits gatekeeper. Caster (2004) argues that it is very important in society to have the meaning and experience built through the aspects of identity such as name, language, religion, culture and so on. It works differently between self and others, thus giving meaning to the existence of self and others which leads to socio-cultural formation.

We know of no people without names, no languages or cultures in which some manner of distinction between self and other, we and they, are not made...self-knowledge - always a construction no matter how much it feels like a discovery - is never separable from claims to be known in specific ways by others.

Hence through this study, the process of identifying the changes that occur can either can lead to the extinction of this society or the development in a different form with a change of system that leads to a new dimension of Orang Asli society. They will only remain a record in history which in actual fact, the role and formation of the early culture of the Orang Asli society is very important in the history of the development, civilization and heritage of the entire Nusantara region.

\subsection{The Origin and Concept of Orang Asli}

Like all ethnic groups, the Orang Asli community is divided into three (3) ethnic groups formed from 19 tribes. The community has a very unique cultural identity, rich in various aspects when discussing each ethnic group. They are a strong community with customs and values inherited from the previous generation (Juli Edo, 2000).

Orang Seletar, Duano and Kanaq are the 3 sub-tribes of the Orang Laut that can be found in Malaysia (more subtribes of Orang Laut or Orang Selat can be found in Riau Islands, Indonesia). These three sub-tribes have been combined with the Jakun and Temuan tribes as the Proto Malays, one of the three groups of Orang Asli (Aborigines of Peninsular - besides the Malays) recognized by the Malaysian government. Just like the Orang Laut, the Jakun and Temuan are also the sub-ethnics of the Old Malay, but they live on land. They are known as Orang Darat.

Orang Seletar can be found around the coast of Johor Bahru district. The name Seletar was taken from a place called Seletar in Singapore. Originally they inhabited the Tebrau Strait and the Singapore Strait before slowly moving (being moved) to Johor. This migration reached its peak in the early years of Singapore's separation from Malaysia. Today, the Orang Seletar in Singapore is declared extinct either due to death or assimilated with the Malay-ethnic. In Malaysia, Orang Seletar still continue to live their traditional way of life despite staying permanently on the coast. Orang Seletar was slow in accepting Islam whereby some embraced Christianity and Buddhism. The Seletar language, just like the catastrophe confronting their settlements, is slowly dying. It is drowned by other groups of languages that are more dominant around it. Although originally only $20 \%$ of Seletar's vocabulary is similar to Malay language, the Seletar children are now more comfortable speaking Malay.

Orang Duano originated from Bengkalis Island (Sumatra) before spreading to many other islands around the Straits of Malacca, the west coast of Johor and the south east coast of Sumatra. In Johor, the Duano inhabit the confluence of rivers in Batu Pahat and Pontian, but some of them were transferred to permanent settlements in Kota Tinggi. The language of the Orang Duano is different from Malay language, but it can be said that this language will soon be extinct as the young generation prefer to speak Malay as taught in schools. I have seen the lives of the Duano people in Kampung Bumiputra Dalam in Rengit, Batu Pahat and their assimilation with the Malays is clearly visible. From the information that I obtained, the younger generation not only do not understand the Duano language, but they are also ashamed to be labeled 'Orang Asli'. For the purpose of distinguishing them from the Malays, they are more comfortable to be called Orang Melayu Kuala. In Malaysia, the Orang Duano are Muslims.

Orang Kanaq are the smallest sub-tribe of the Orang Laut from Malaysia and Indonesia. The number that can be traced to this day is only 87 people, all living in Kampung Sungai Selangi, Kota Tinggi, Johor. The findings of the field work also concluded that none of the Kanaq tribes in the Riau Islands were found even in their own place of origin in Sekanak Island, a small island in northern Batam. Based on historical records (The Sosioeconomic History of The Orang Kanaq of Johor, Mahani Musa, 2011), the Orang Kanaq were brought to the mainland of the Peninsular during the Sultanate of Johor for the purpose of supplying forest products. However, they failed to do so because they 
were not accustomed to living on land until they were neglected and unable to develop their own economy. On the welfare of the Johor state government, each family was awarded 10 hectares of land to work on besides one special village for them in Kota Tinggi (Kampung Sungai Selangi, now). However, the sea instincts in their lives were not easy to erode, the land that they were blessed were not cultivated and were leased to Chinese entreprenuers. Living in a special village had also prevented the Orang Kanaq from exposure to the outside communities surrounding them. Since the time of the Sultanate of Johor, the Orang Kanaq had embraced Islam. Nevertheless, the traditional beliefs of their tribe still remain to this day. It also relates to the limited socializing of this tribe with the outside communities. The children of the Orang Kanaq are still reluctant to go to school, despite being given various assistance. According to a researcher, the 'Orang Asli' label is increasingly isolating them from continuing to compete with the outside world. But there is one good thing, the Kanaq language is preserved to this day. The language is able to withstand the test of time and is spoken by all generations although its vocabulary is slowly being replaced by the Malay language vocabulary through the mass media.

Orang Asli is one of the indigenous tribes grouped in the native Malay tribe. According to Juli Edo (2000), the grouping was carried out by the British when administering Malaya as one of the efforts to overcome poverty problem in order to develop indigenous people. However, the term Orang Asli is often used and widely used by the Orang Asli Development Department (JAKOA), an agency responsible for Orang Asli affairs in Peninsular Malaysia. According to Mr. Osman Bungsu (2017), the term Orang Asli changes according to place, whereby in Johor, they are known as Orang Laut or Orang Kuala based on the location of their settlements whether at the sea shore or coast of Johor. It is said that this tribe originated from the coastal areas of Riau, and this is different from the Orang Asli community in other states such as in Pahang and Kelantan, where the Orang Asli are much more populated in the interior of the districts in these states.

Orang Kuala was a title given to them in Johor. Originally, this group was known as Orang Laut, a group of 'indigenous tribe' in Riau. Orang Kuala or in their tribal tribes known as the Duano tribe are one of the 18 tribes of the Orang Asli in Malaysia. They belong to the Proto Malay group, one of the main groups of the Orang Asli. In the Malay historiography, it is also stated that the Proto Malay communities were living in the southern region of the peninsula of Malaysia and we cannot dismiss that this group was in Johor.

Tracing the history of Duano tribes in Rengit, Minyak Beku and Kota Masai is not easy because there are not many written documents explaining the arrival of these tribes in Malaya or Malaysia. According to Nazarudin Zain, 2015, based on interviews with the old generation, there are various opinions regarding the history of the Duano tribe in Benut and the history of the origins of this group. Some have argued that the settlement of the Duano tribe in Benut has existed since 1928 and their initial settlement was located at the Benut River. The title given to them, Orang Kuala is due to the location of their settlements near the confluence of rivers or the coastal area.

They are widely placed in the Johor region like Pontian, Rengit and Minyak Beku. This is because of the location of settlements which are at the confluence of rivers and coastline near the rivers. Once upon a time, this group was evenly distributed on the beaches on both sides of the Straits of Malacca, including the Malay Archipelago.

In the context of our country, although they are called Orang Laut but the Malaysian government categorized them as Orang Asli. This is enshrined in Act 134 which gives the privilege to the Orang Asli community and on the administrative aspect facilitates the development of this community.

The tribesmen of Orang Kuala do not like being called Orang Kuala. In their view, the term is usually used by outside communities to mock them. Hence, they are more comfortable to be called Orang Laut or Orang Asli or Melayu Asli and some favour to be known as Orang Duanu. But in fact, the tribemen of Orang Kuala are a sub-race to the Malay Proto / Asli. They are known as Orang Kuala due to their earlier settlements which were in the confluence of rivers and lives as fishermen. The tribesmen of Orang Kuala often call themselves Orang Laut, while the Orang Asli on land as Orang Asli Darat or Orang Sakai.

The Orang Kuala are indeed known as Orang Laut. However, in the large group of Orang Asli, besides Orang Kuala. Orang Laut also refer to Orang Seletar and Mah Meri (or also Ma 'Betisek or Besese). All Orang Kuala are Muslims, interestingly, they are different from other Orang Asli, the Orang Kuala are not new to Islam, but they are Muslims since their ancestors' time. In fact some of them regard themselves as the Malay race on the grounds that they are not converts, but the original Muslims as the Malays. Some older people also claim that they have a bond with the 
indigenous people in Riau Indonesia. However, if based on the views of Chou (2003) and Andaya (2008), the indigenous people in Riau are not regarded as Orang Kuala, but are called Orang Laut or Suku Sampan.

\subsection{Orang Asli in the History of the Malay Civilization}

The role of the small Malay tribe such as Bajau and Orang Laut is actually big in history. In the writing of Mohd. Affendy Abdul Hamid in Berita Harian dated 13 October 2010, he explains that after examining the story of Orang Bajau, the nomad tribe and sea traders in the waters of the Philippines, Malaysia and Indonesia, Orang Laut were mentioned in the Malay History. These tribal people served the Sultan or the Malay rulers by protecting the sea route.

In 1819, according to British records, Singapore was described as a fishing village. In other words, before 1819 Singapore was not so important. Yet this is not the case. Archaeological studies (excavations) by the historian of Singapore National University, Dr. John Miksic, have exposed the important role of Singapore during the 14th century. This means that Singapore's existence as a trading port has long been in existence since the ancient times. In fact, Thomas Stamford Raffles realized this when visiting Singapore in 1819 to re-establish it as an entrepot port. Dr. Leonard Andaya, in Chapter 6 of the book entitled Leaves of the Same Tree: Trade and Ethnicity in the Straits of Melaka (University of Hawaii Press, 2008), unveils the role of the Orang Laut which was very important in the formation of the Malay kingdoms (spelt as Malayu and not Malays). Orang Laut were regarded as important to be given the honorary ranks by the Malay rulers. They controlled the sea route and at the same time ensured peacefulness which was important for international trade. The Orang Laut were described as very knowledgeable about the sea in terms of seasons, waves, seafood such as fish and the pearls needed for the Chinese market. However, their biggest contribution to the Malay rulers was to preserve the sea route including 'persuading' the merchant ships to stop at the port. Nevertheless, the Orang Laut devotion decreased after major changes occurred in the development of the Malay economy from relying on the sea to agriculture and mining beginning from the late 19th Century AD. In fact, there are very few research on the Orang Laut in terms of their history, culture and thinking. Their presence was to guard the coastal kingdoms of the Straits of Malacca, including the Sultanate of Malacca. Based on their 'isolated' way of life and occasional encounters with people, we need to look into their perceptions about, for example, developing the Malay language and culture in Malaysia and Singapore; the overall impact on the structure of the Orang Laut community since Singapore's separation from Malaysia; the role of Chinese in the history of Southeast Asia - how did the Orang Laut perceive the Chinese community?; How do the Orang Laut adapt to the current Southeast Asian transformation and what are the Orang Laut perspectives about these processes? In an article from The Straits Times dated December 25, 1949, on the Singapore's Orang Laut in the south of Johor, the Chief of the Orang Laut was called 'batin' or 'tok batin'. At that time, there were two tribes of the Orang Laut in Singapore, known as Orang Kalang and Orang Selat. Orang Kalang came from Riau and settled on Kalang Island, but they had to move when the airport was built at that time. Many Orang Kalang live in Pasir Panjang. And the Orang Kalang group is divided into two, namely Orang Kopek and Orang Senggera.

The Orang Selat are said to be followers of Temenggong Abdul Rahman and live on their boats at the estuary of the Singapore River. They acknowledge themselves as the tribe sailing the Raffles' boat to land on the banks of the Singapore River. The description of the economic activities of the Orang Kalang is indeed interesting. They sell young nipah leaves to make cigarette papers. They collect the nipah in the Riau Islands using small sailboats called 'perahu pucuk'.

M. Effendy A. Hamid goes on to say, though the Orang Laut are said to be uneducated or are said to shy away from progress, these are not true. Some are able to adapt to change, persistent and profoundly perserve their dignity, and proud of their origin as 'Singapore's Orang Asli' like the former cabinet minister, Haji Othman Wok. Being addressed as Orang Asli is not suitable with their community structure. This makes them unhappy to be categorized as Orang Asli. According to them, there are several factors why they refuse to be categorized as Orang Asli. First, they are Muslims but the Orang Asli are not. Orang Asli is also known as Orang Asli Darat and most of them practice Christianity. In fact, they claim to be Muslims and should be considered as native to the local Malays. Secondly, with regard to the Islamic religion they are prohibited from eating pigs and rearing dogs whereas the Orang Asli community can eat pigs and are allowed to rear dogs.

It is wise to study this before the story of the Orang Laut is no longer known and this tribe becomes extinct. 


\section{Research Methodology}

This study was conducted using qualitative approach, which emphasizes the quest for meaning and process, Stephen \& Kasim (2015) explains that qualitative research is the process of digging the understanding of meaning and describing the reality investigated in depth and is multifaceted, complex and involves development of theories. The use of qualitative approach is based on the determination to understand and do an indepth review of the process of structural change in society and the association with the determination of the identity of the socio-cultural interaction of society which on the verge of climishing. The collected data will prove to be the precise truth, strengths and weaknesses to the explanation provided.

The study was carried out in several Orang Asli villages of the Orang Kuala or Duano in Batu Pahat, Johore and specifically at three main locations namely Rengit, Minyak Beku and Kota Masai. The selection of these locations was made because of the uniqueness shown which are different from other indigenous people. Among the uniqueness shown are the family structure and their socio-cultural concepts of transforming their economy, education and life through participation in the economic activities of the people of Johore. Orang Kuala Rengit and Minyak Beku have participated in the import of used goods while the Orang Kuala in Kota Masai usually carry out sea-based economic activities which are selling of marine products in the morning and evening to the local community. Indirectly, they have opened many job opportunities to their family members as well as to the local communities.

Through the use of qualitative approaches, researchers also obtain research materials using various means, which involve references to written abstracts (historical books, archives). Rich data collection in the field at the three main locations specifically in Rengit, Kampung Minyak Beku and Kota Masai in Johor are information on the similarities dan differences among them although at a glance they may look alike. The collection and analysis of written materials are very important to obtain a comprehensive picture, revealing the historical beginning of the existence and development of this society in Malaya and the Archipelago. Selection of locations through field-based research is focused on the role of individuals in the community, the position, the layers of different generations obtained through interviews and observations.

Interviews were conducted with every Tok Batin of the Orang Kuala at each place, several family members, resident associations and a few traders involved in their economic activities. Both structured and independent interview methods are used repeatedly by providing questions related to the role and position of informants in their groups. Researchers also took repeated observations to ensure that the validity and reliability of the phenomenon seen is a real phenomenon and not momentary. This is because the uniqueness shown is different to the Orang Asli community as compared to other societies. Repetition of interviews and observations also help researchers to organize and conduct effective trangulation checks during data analysis process and discusion. This is to assist the researcher to familiarize with these community and to promote mutual friendship to ease the sharing of information.

\section{Discussion}

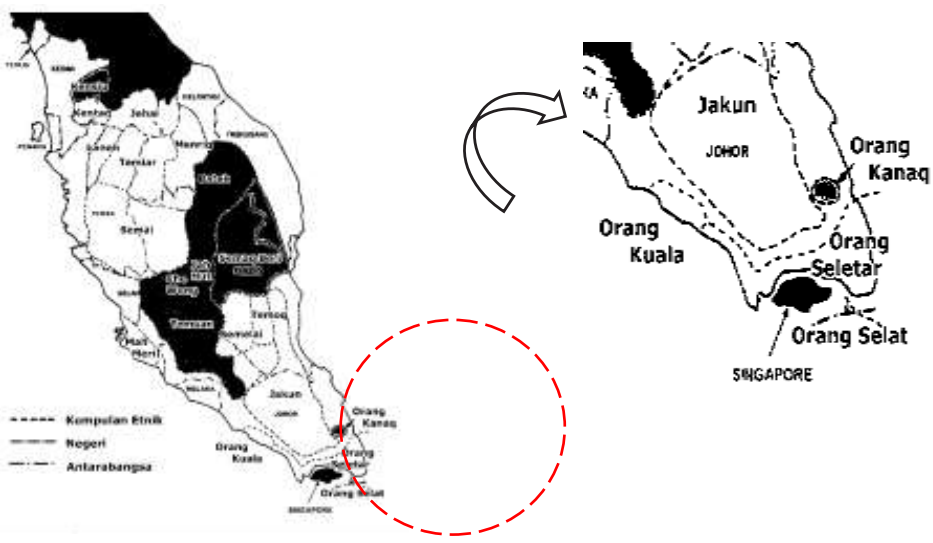


Figure 1: The Settlements of Orang Laut/Kuala in Johor

\subsection{The Development of Sociocultural Aspects of Life}

The discussion focuses on the 3 villages studied. The map in Figure 1 shows that the location of distribution of the Orang Kuala is very closely related to the sea and indirectly their lives cannot be separated from the sea and sea products. In the past, the Orang Laut community lived in a type of boat house called 'sampan panjang'. However, they often move from one place to another to preserve sustainability of their lives which are self-reliant in nature. At the beginning of the Orang Kuala historiography, they were placed everywhere in the form of small settlements based on the tribe or group of their family members. However, after Malaysia achieved its independence they were then placed in well-organized and structured village areas which were provided by the government under the responsibility and administration of the Department of Orang Asli Affairs (Pelras, 2002).

Analyzing the structure of society and the Sociocultural Interaction Identity of this community can be viewed through three main aspects namely the development of languages and dialects, economic activities, customs, religions and practices, and changes in locality of settlements and interaction patterns. Overall, the growth and development of an area influence the changes in the structure of the community and consequently affect the sustainability of sociocultural identity. If viewed through the timeline, changes in the sociocultural aspects are quite different in comparison with the original structure of the community.

\subsection{Development of Language and Dialect}

In general, language is a system of sound symbols used by members of a community to collaborate, interact, and identify themselves. The language function can be divided into two, namely the general language function and the specific language function. The general language function includes as a communication tool, as a means of expression and as a means to adapt and integrate socially. While the specific language function is aimed at the practice of a culture, and most importantly is to gain knowledge.

Dialects can also be associated with variations of a group of speakers located at a place, region, or area. In other words, dialects are uniformed ways of pronunciation or styles of language use. The variances in dialects occur due to social and regional differences.

As such, the aspect of language and dialect is also one of the important aspects to be observed in a community. However, those called Orang Kuala usually use the same Malay language and dialect as the local Malay community in Johore. They are more comfortable using Malay language than the dialect of language they have practiced since long ago. They only use their language and dialect when they talk to each other to facilitate understanding and instruction they want to achieve.

\subsubsection{Orang Kuala Rengit}

This community group lives on the edge of Sungai Rengit, in the confluence of the Batu Pahat River. Their village area is formed in line with the direction of the river. The Village Head is appointed by the local authorities with reference to 'their elders'.

Most Orang Asli Rengit interact with the Malay and Chinese communities around Batu Pahat Town. Interaction with the local communities takes place due to the aspect of education, where they send children to schools around the area. Many Chinese traders around Rengit area influence the development of this community. The use of Malay language and Chinese dialect in everyday spoken exchanges has altered their language structure and reduced the language use.

This change is also due to intermarriages between the Orang Asli community and the Malay population in that area. Young people who are mostly exposed to external culture and social media have influenced the retention of the language of this community. The use of telephones, television station networks, and the internet brings a lot of impacts to the younger generation in particular. 


\subsubsection{Orang Kuala Minyak Beku}

The use of their language has started to decrease due to their increasingly scattered settlements, usage of Malay language in daily interactions either in schools, communities or with other community groups. The Minyak Beku community are not much different from the people in Rengit, because of the geographical structure that places these two settlements in parallel. If in Rengit there is settlement separation, in Minyak Beku almost $70 \%$ have lived in Malay villages. Intermarriages between the Malay community and the Orang Kuala are no longer strange.

\subsubsection{Orang Kuala Masai}

Based on observation, the Orang Kuala Masai are still using their language and dialect in their daily activities. On the other hand, the Orang Kuala in Rengit and Minyak Beku have long been using the local Malay language because most of their residences are located near each other, and it is also easier to interact with the local communities.

\section{Economic Activities}

During the 70s, their main economic activities were fishing, and becoming fish retailers. However, with the development of the Rengit town, the economic activities have changed. They began to change their economic activities, the Johore Government also encouraged them to run the bundle business of household necessities such as furniture, electrical goods, kitchen utensils, clothing and toys. Initially, they started businesses on a small scale in their settlements and were just doing business in front of their houses. The Orang Laut have the unique identity of a community who cherish, adore and are close to the sea, symbolizing the 'who and the origins' of the sea as a source of livelihood and economic resources to them. The seas surrounding the Straits of Malacca have rich resources and become part of the development area of the community system. However, after the Department of Orang Asli Affairs has taken on the role of managing this community, they have been given the privilege by the Johore State Government to help stimulate the development of the Orang Asli community by promoting economic activities in a particular area.

\subsection{Orang Kuala Rengit}

The Orang Kuala Rengit showed an increase in their economic activities in line with the community's development. Compared to the 1980s, the community have now advanced as traders and some still remain as seafarers. The demand for fish from the local market makes this inherited economic activity a priority to them.

In fact, some of them are active in running workshops of used goods in Kampung Bumiputra Dalam, Rengit Batu Pahat (in Figure 2). They have long been involved in economic activities and at the same time help to increase their family income. Most of them run businesses such as selling imported furniture from Singapore which are in good condition and can still be used (in Figure 3).

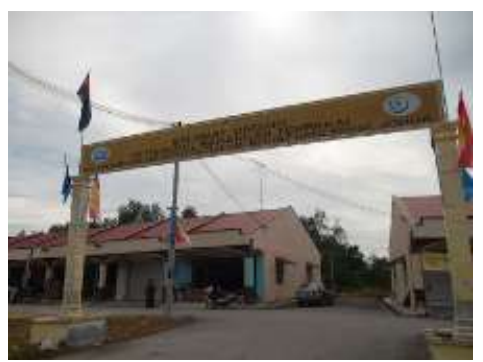

Figure 2: The Entrance to the Village of the Orang Kuala Rengit 


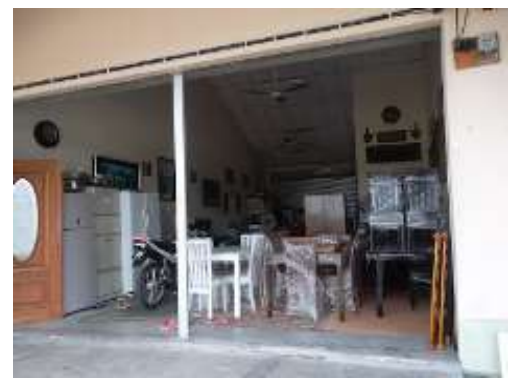

Figure 3: Used Furniture Sales Managed by Orang Kuala Rengit

\subsection{Orang Kuala Minyak Beku}

A visit to the Minyak Beku area showed that they have moved their settlements from the Batu Pahat riverbank area to the village area. The opening of quarry and shipbuilding companies as well as small ports in Minyak Beku has changed the structure of their settlements. However, most who were seafarers have been working with the Chinese and some are still the buyers or sellers of fish in the market. Several tables in the market are run by the persistent Orang Kuala sellers along with the Chinese and Malay sellers. What is interesting, if the mother is selling, then the children will also take part and they will not attend school. Some are also involved in the business located in the Orang Kuala Market at Jalan Pasar (behind the public market in Figure 4). They place their bundle sales daily from 8am until 12pm at Jalan Pasar. The bundle sales run by them include selling second-hand electrical goods at reasonable prices (in Figure 5).
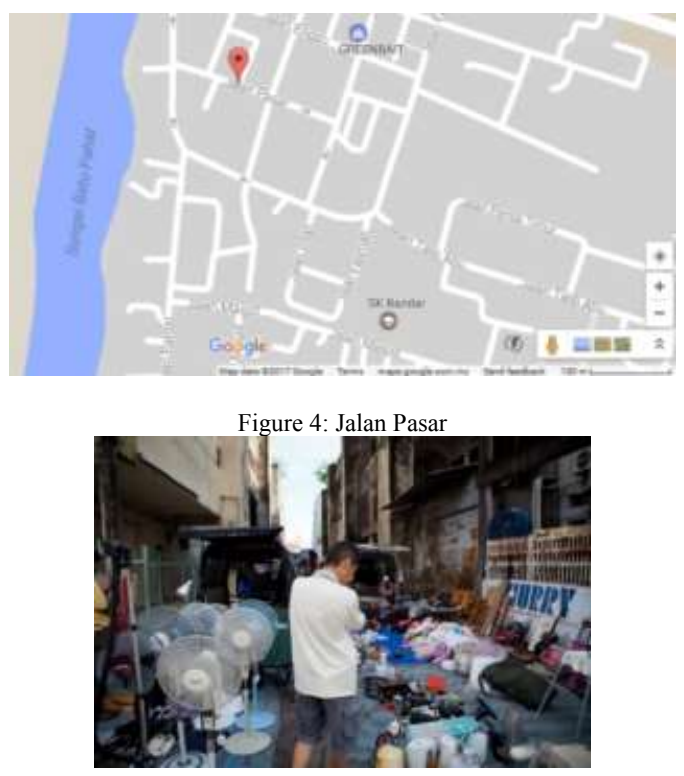

Figure 5: Bundle Sales 
They are no longer involved with economic activities in Batu Pahat. This is because they accept employment as government employees as their permanent jobs. They are more comfortable when grouped together with the local Malay community.

\subsection{Orang Kuala Kota Masai}

The Kuala Kota Masai village is located at the end of the Johore causeway in Pasir Gudang, near the Johore Fisheries Department's Fish Collection Center, the Y-shaped junction separates the Malay village and the Orang Seletar village, in contrast to the people of Kuala Minyak Beku that live among the Malay community. The main focus of this community is to become seafarers. In the village, 76-year-old Tok Batin Nah bin Bechik is the second tok batin after his father. The village is located on the edge of the Tebrau Strait. The economic activity of this community is selling of fish hauled.

According to William, the son of an Orang Selatar:

"Setiap pagi kami akan ke laut untuk menangkap ikan. Kebanyakannya kami akan dapat ikan yang besar-besar seperti ikan merah, ikan siakap, ikan pari dan banyak lagi. Setelah pulang, kami akan agihkan ikan tersebut kepada peniaga makanan dan selebihnya kami akan membuat jualan di pasar-pasar besar dan di pasar Orang Kuala Kampung Masai."

("Every morning we will go to the sea to catch fish. Mostly we will be able to get big fish like snapper, seabass, stingray and many more. After returning home, we will distribute the fish to the food traders and the rest will be sold in the big markets and in the Orang Kuala Kampung Masai market.”)

$P 1, K K M, 2$

This is proven by the sales of fish operated by themselves in some areas such as their own village and some neraby markets (in Figure 6).

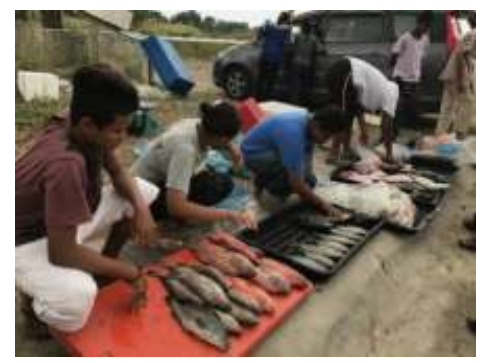

Figure 6: William (left - in red) along with family members running their business of selling sea products every 5 pm at the entrance of their village in Kota Masai.

"Ikan tak macam dulu, dulu banyak sekarang dah berkurangan, pembangunan di tambak menjadikan bekalan sumber laut berkurang...macam saya sebagai Tok Batin dapat elaun manakala yang lain masih menjadi nelayan."

("The amount of fish has now decreased, the development of the causeway has reduced the supply of marine resources ... for me I get allowance as a Tok Batin unlike others who remain as fishermen.")

The government also provides a site to enable them to sell their catch. The sales area is on the outskirts of their village. Based on observation, the price of fish sold is cheaper than in the market. Among the catch they often get is grouper, red snapper, seabass, big eyes, snapper, cockles, crabs and promfret. Their catch is also reserved by restaurants around Johor Bahru. Some of them have their own vehicles like William's father who has become a supplier to several seafood restaurants. The demand among buyers is still encouraging so they are still fishing in the sea and selling their catch at a good price. 


\section{b. Customs, religions and practices}

According to informants, the migration of the Orang Laut from their ancestors in Riau and islands around the Archipelago is similar to the Malays in terms of culture, religion, customs and language. The language of this group is known as Orang Laut language which includes various types of tribal accents. They generally seek livelihood by working as fishermen. Apart from being characterized as a group linked to the sea, they are identified as Muslims.

They are also known as Orang Lanun or Orang Selat because before they devoted their loyalty to the Srivijaya Kingdom, they were originally a group of sailors (some authors named them pirates) who guarded the area around the Straits of Malacca. They controlled the boundaries of the sea, chased out pirates, led the merchant ships to the destination port, took care of business activities and became the messenger for governments around the Straits of Malacca. Due to the position of Orang Laut who knew the intricacies of the sea around the Straits of Malacca described in the History of the Malays to be among the busiest sea route, they played an important role in the reign of the Kingdom of Srivijaya, the Sultanate of Malacca and later to the Sultanate of Johore-Riau. Their duty as warriors or police in the sea led to a close relationship between the Orang Laut and the three royal institutions that had been established since the early days of the reign of Srivijaya kingdom. Orang Laut were also known as a very loyal group to the royal family of Srivijaya. Even after the fall of Srivijaya in 1025, Orang Laut continued to be devoted to Parameswara, the last prince of Srivijaya (Palembang). Changes in the Johore-Riau sultanate system in 1699 also occurred when the 11th Sultan Mahmud Syah died as a sultan who was still single, then the throne was replaced by the Bendahara who appointed himself as the 4th Sultan Abdul Jalil which caused the Orang Laut not to recognize the new Sultan of the Johore-Riau Sultanate. Finally, by the 18th century, the role of the Orang Laut as the peace keepers of the Straits of Malacca was slowly being replaced by the Orang Bugis.

\subsection{Orang Kuala Rengit}

Their customs, religions and practices have changed considerably in particular due to changes in religious beliefs. Some people of the Orang Kuala Rengit community are also Muslims, in the village of Kuala Rengit a surau was built since the 1990s. The Malay custom became their custom as they celebrate all the festivals of the Malay community.

\subsection{Orang Kuala Minyak Beku}

The Minyak Beku community are not much different from those in Rengit, because of the geographical structure that places these two settlements in parallel. If in Rengit there is a settlement separation, in Minyak Beku almost 70\% have been living in the Malay village. Intermarriages between the Malay community and the Orang Kuala was no longer strange. There are already those who wear Islamic clothes with veils, covering aurat and practicing the cultures of the Malay.

\subsection{Orang Kuala Kota Masai}

The settlement of this community differs from the previous two settlements, their location is quite isolated and far from development. Judging from the customary aspect, they are still bound by the family structure and the 'tok batin' as the leader. Tok Batin Nah bin Bechik has determined his successor. In this community, Tok Batin Orang Kuala Kota Masai has nine (9) children and two (2) of them have married the Chinese and their children use the Chinese name in their identity card. In the presence of the researchers, they were actively discussing the 'modern sewang' event called the joget night which will be held in Setulang, the village of the Orang Kuala Selatar, in Johore. Although some of these families are Muslims, the Islamic characteristics are very few and the emphasis on Islam can only be seen on identity cards. Some even have adopted other religions as a result of mixed marriages with the local Chinese.

\section{Changes in the Location of Settlements and Interaction Patterns}

\subsection{Orang Kuala Rengit}

For the Orang Kuala Rengit, the development provided by the government has given them a lot of benefits. Former Senator Mr. Othman Busu in an interview said the government always provided an opportunities for the Orang Kuala 
community to carry on business especially around Bandar Rengit and Batu Pahat. Mr. Othman himself is a supplier of teak furniture to the Orang Kuala traders. They are also traders at the Pasar Orang Kuala in Bandar Batu Pahat by offering clothes, home appliances, furniture, and reusable decorative items. The demand for goods turned them from fishermen into traders. Nonetheless there are still those who remain as fishermen by providing fresh fish to the locals. The impact of this economic activity led to a wider interaction patterns, with the Malay language as the medium of their communication.

\subsection{Orang Kuala Minyak Beku}

The community in the outskirts of Batu Pahat are affected by the rapid development of the city. Interactions with the Malay, Chinese, Jawi Peranakan (Arabs) and Indian communities are very clear due to the location of their settlements and also economic activities. In addition, their involvement in the public market of Batu Pahat as part of the traders shows a more complex pattern of interaction with other communities.

\subsection{Orang Kuala Kota Masai}

The Kuala Seletar community hardly mix with the outside communities, but they deal with the same buyers when selling fish, purchasing household supplies, which involve them interacting with outsiders. Their relatives live in other villages because according to Tok Batin Nah bin Bechik, each village can only have a leader, so every village is usually inhabited by a nuclear family.

\section{Conclusion}

Studying the restructuring of the Orang Kuala community by analyzing it specifically into interaction patterns, economic activities, and religious practices shows a minority group of community who are beginning to become extinct.

From the aspect of the structure of community, the change of settlements, development and practice of intermarriages have begun to break through the walls of this community which has weaken the traditional values, customs, and language. The birth rate in this group of community is also shrinking, if the head of the family or Tok Batin has nine (9) children, he states that his father has 19 children, but his own children have only three (3) or two (2) children. Similarly, the Orang Kuala at Rengit and Minyak Beku, almost all showed a decreased family size.

If viewed from the beginning it is imperative that as a minority community, they need to foster interactions with the local communities to secure their position in the world-view. From the perspective of the use of parent language, almost all new generations are not fluent in their mother tongue. Most have been using the Malay language as formal education is received from schools and through interactions with the local communities.

In terms of economic activities, however, after a long time as seafarers, having mastered and understood the sea but with the changes of development and technology, and lack of marine resources, have made them begin to move on to land activities. Furthermore, with the supervision of the Johore state government, many business opportunities are provided for them to show their potential in the economic field as they have been allowed to trade in an area reserved for them especially in Batu Pahat. That area is located in the Batu Pahat market and their businesses are still ongoing until today. Obviously, their potential in the economic field is extensive and good.

The continuity and sustainability of the Orang Kuala's culture as we see in the communities of other countries such as the Aborigines of Australia, and the Red Indians in the United States have had a profound impact from the development and technology of the modern world. 


\section{References}

1. Andaya, L. A. Leaves Of The Same Tree-Trade And Ethnicity In The Straits If Malaka (2008).

2. Castell, M. The power of identiti. Edisi ke-2 (2004).

3. Chou, C. Indonesian Sea Nomads Money, Magic And Fear Of The Orang Suku Laut (2003)

4. Giddens, A. Sociology (2008).

5. Giddens, Anthony. Teori Strukturasi : Dasar-dasar Pembentukan Struktur Sosial Masyarakat (2011).

6. Google Maps. Maps of Jalan Pasar retrived on 14 April 2017 at https://www.google.com/maps/place/Jalan+Pasar,+83000+Batu+Pahat,, Johor,, Malaysia/data=!4m2!3m1! 1s0x31d056c6a2e06537:0x228c075936af601f?sa=X\&ved=0ahUKEwiQkpzRiKPTAhWDwI8KHcHsB9w Q8gEIITAA dan maintained at 2017 (2017).

7. Juli Edo, Dari darat ke laut: Singkapan ringkas etnosejarah Orang Asli di Johor.At Seminar sejarah dan budaya Johor, anjuran Kerajaan Negeri Johor, 3-6 Mei 2000. (2000).

8. Just Faaland, Jack Parkinson \& Rais Saniman, Dasar Ekonomi Baru: Pertubuhan Negara dan Pencapaian Ekonomi Orang Melayu. . (2005).

9. Pelras, Christian, (A few jottings on some aquatic populations of the Nusantara Archipelago. Retrived on 14 April 2017 at Http://www.keene.edu/library/OrangAsli/ pelras.pdf. (2002).

10. Mahani Musa. The Sosioeconomic History of The Orang Kanaq of Johor. Kajian Malaysia, Vol. 29, No. 1, 2011, 47-74. (2011).

11. Siti Rahmah Wahab. Adaptasi Sosiobudaya Orang Laut di Kecamatan Tanah Merah, Kabupaten Indragiri Hilir, Riau, Indonesia. Thesis published. (2015).

12. Stephen Kwadwo Antwi \& Kasim Hamza (2015). Qualitative and Quantitative Research Paradigms in Business Research (Journal of Business and Management [Online]) Vol.7, No.3, 2015 217. Retrived on 14 April 2017 at www.iiste.org. Tamale: School of Business, Tamale Polytechnic.

13. Zainun, Nazarudin. Antropologi Dan Sejarah Dalam Kearifan Tempatan. (2015) 